\title{
THERMODYNAMIC PROPERTIES AND MICROSTRUCTURES OF DIFFERENT SHAPE-MEMORY ALLOYS
}

\author{
TERMODINAMIČNE LASTNOSTI IN MIKROSTRUKTURA \\ RAZLIČNIH ZLITIN Z OBLIKOVNIM SPOMINOM
}

\author{
Lidija Gomidželović1, Emina Požega' ${ }^{1}$, Ana Kostov ${ }^{1}$, Nikola Vuković², \\ Dragana Živković ${ }^{3}$, Dragan Manasijević ${ }^{3}$ \\ 1Mining and Metallurgy Institute, Zeleni bulevar 35, 19210 Bor, Serbia \\ ${ }^{2}$ University of Belgrade, Faculty of Mining and Geology, Đušina 7, 11000 Belgrade, Serbia \\ ${ }^{3}$ University of Belgrade, Technical Faculty, VJ 12, 19210 Bor, Serbia \\ lgomidzelovic@yahoo.com \\ Prejem rokopisa - received: 2014-08-26; sprejem za objavo - accepted for publication: 2015-02-06
}

doi:10.17222/mit.2014.212

\begin{abstract}
The results of a thermodynamic-properties calculation conducted using a general solution model (GSM) and an experimental investigation of the microstructures of different shape-memory alloys (SMAs) are presented in this paper. The investigated alloys belong to ternary systems $\mathrm{Cu}-\mathrm{Al}-\mathrm{Zn}$ and $\mathrm{Cu}-\mathrm{Mn}-\mathrm{Ni}$ and to quaternary system $\mathrm{Ni}-\mathrm{Cu}-\mathrm{Fe}-\mathrm{Mn}$. The examinations were conducted using light microscopy (LM) and scanning electron microscopy with energy-dispersive X-ray spectrometry (SEM-EDX).
\end{abstract}

Keywords: thermodynamics, shape-memory alloys, microstructure, LM, SEM-EDX

V tem članku so predstavljeni rezultati termodinamičnih izračunov lastnosti, ki so bili izvršeni z uporabo splošnega modela rešitev (GSM) in eksperimentalne preiskave mikrostrukture različnih zlitin z oblikovnim spominom (SMAs). Preiskovane zlitine pripadajo ternarnim sistemom $\mathrm{Cu}-\mathrm{Al}-\mathrm{Zn}$ in $\mathrm{Cu}-\mathrm{Mn}-\mathrm{Ni}$ in kvaternarnem sistemu Ni-Cu-Fe-Mn. Preiskave so bile izvedene $\mathrm{s}$ pomočjo svetlobne mikroskopije (LM), z vrstično elektronsko mikroskopijo (SEM) in z rentgensko energijsko disperzijsko spektrometrijo (EDX).

Ključne besede: termodinamika, zlitine z oblikovnim spominom, mikrostruktura, LM, SEM-EDX

\section{INTRODUCTION}

Shape-memory materials are able to recover their original shape after being distorted, at the presence of the right stimulus. These materials include: a) shape-memory alloys, b) shape-memory polymers, c) shape-memory composites and newly developed d) shape-memory hybrids ${ }^{1}$.

The shape-memory effect was first discovered for a gold-cadmium alloy in the 1930s, but this type of behavior of materials did not attracted the attention of the researchers until 1960s, when a significant recoverable strain was observed for a Ni-Ti alloy, enabling commercial applications.

Shape-memory alloys (SMAs) are characterized by unique properties (pseudoelasticity and shape-memory effect), which enable them to "remember" their original shapes. These alloys are used as activators, changing their shapes, positions and other mechanical characteristics in a response to a variation in the temperature and electromagnetic field.

SMAs can be classified, in accordance with the alloying metals, into:

1. Alloys based on nickel (Ti-Ni, Ni-Mn-Ga)

2. Alloys based on copper $(\mathrm{Cu}-\mathrm{Zn}-\mathrm{Al}, \mathrm{Cu}-\mathrm{Zn}-\mathrm{Si}, \mathrm{Cu}-$ $\mathrm{Zn}-\mathrm{Sn}, \mathrm{Cu}-\mathrm{Zn}-\mathrm{Ga}, \mathrm{Cu}-\mathrm{Zn}-\mathrm{Mn}, \mathrm{Cu}-\mathrm{Zn}-\mathrm{Al}-\mathrm{Ni}, \mathrm{Cu}-\mathrm{Zn}-$ $\mathrm{Al}-\mathrm{Mn}, \mathrm{Cu}-\mathrm{Al}-\mathrm{Ni}, \mathrm{Cu}-\mathrm{Al}-\mathrm{Be}, \mathrm{Cu}-\mathrm{Al}-\mathrm{Mn}$ )
3. Alloys based on iron (Fe-Mn, Fe-Ni-C, Fe-Mn-Cr, $\mathrm{Fe}-\mathrm{Mn}-\mathrm{Si}$, Fe-Ni-Nb, Fe-Co-Ni-Ti)

4. Alloys based on noble metals (Au-Cd, Au-Ag, Pt-Al, $\mathrm{Pt}-\mathrm{Ga}, \mathrm{Pt}-\mathrm{Ti}, \mathrm{Pt}-\mathrm{Cr}$ )

5. Exotic alloys (In-Te, In-Cd, V-Nb) ${ }^{2}$.

The interest in SMAs is continuously increasing as new areas of application are discovered. Today, SMAs are used in different areas such as civil engineering ${ }^{3,4}$, the production of microsystems 5 , medicine ${ }^{6-8}$, earthquake technologies $^{9-11}$ and robotics ${ }^{12,13}$.

The first copper-based SMA to be commercially exploited was the $\mathrm{Cu}-\mathrm{Al}-\mathrm{Zn}$ alloy and the shape-memory alloys from this ternary system typically contain mass fractions of $w(\mathrm{Zn})=15-30 \%$ and $w(\mathrm{Al})=3-7 \%$.

$\mathrm{Cu}-\mathrm{Mn}-\mathrm{Ni}$ shape-memory alloys are magnetic, but some of their properties (like the brittleness) limit their applications, so the alloying elements like gallium, iron or aluminum are added to an alloy in order to achieve satisfying characteristics.

The objective of this work is to provide some new information about the thermodynamics and microstructures of selected shape-memory alloys. 
L. GOMIDŽELOVIĆ et al.: THERMODYNAMIC PROPERTIES AND MICROSTRUCTURES ...

Table 1: Composition, shape and production method of investigated samples

Tabela 1: Sestava, oblika in način izdelave preiskanih vzorcev

\begin{tabular}{|c|c|c|c|c|c|c|c|c|c|}
\hline \multirow{2}{*}{ Sample } & \multirow{2}{*}{ Alloy } & \multicolumn{6}{|c|}{ Composition $(w / \%)$} & \multirow{2}{*}{ Shape } & \multirow{2}{*}{ Production method } \\
\hline & & $\mathrm{Al}$ & $\mathrm{Cu}$ & $\mathrm{Zn}$ & $\mathrm{Mn}$ & $\mathrm{Ni}$ & $\mathrm{Fe}$ & & \\
\hline A1 & NiCuFeMn & I & 32 & I & 1.5 & 65 & 1.5 & rod, $R 1.27 \mathrm{~cm}$ & casting \\
\hline $\mathrm{A} 2$ & $\mathrm{CuMnNi}$ & 1 & 84 & 1 & 12 & 4 & 1 & wire, $R 1 \mathrm{~mm}$ & casting, extraction \\
\hline A3 & $\mathrm{CuAlZn}$ & 4.54 & 68.14 & 27.31 & 1 & 1 & 1 & wire, $R 3.5 \mathrm{~mm}$ & casting \\
\hline A4 & $\mathrm{CuAlZn}$ & 5.7 & 68.27 & 26.03 & I & 1 & 1 & rod, $R 8 \mathrm{~cm}$ & casting \\
\hline
\end{tabular}

\section{EXPERIMENTAL WORK}

The characterization of the selected shape-memory alloys was done using light microscopy and a SEM-EDX analysis. The samples were obtained from the industrial production. The composition, shape and production method of the investigated samples are given in Table $\mathbf{1}$. The samples were used as prepared (no annealing).

The microstructural analysis of the investigated samples was performed with light microscopy (LM), using a Reichert MeF2 microscope (a magnification of up to $500 \times$ ) and a SEM-EDX analysis performed on a JEOL JSM-6610LV scanning electron microscope (a magnification of up to $300000 \times$ ) coupled with an Oxford Instruments, X-Max $20 \mathrm{~mm}^{2}$ SDD, energy-dispersive $\mathrm{X}$-ray spectrometer (an accelerating voltage of $20 \mathrm{kV}$ and a beam current of $1.25 \mathrm{nA}$ ). Prior to the metallographic analysis, the surfaces of the polished samples were etched with an appropriate etching solution (Table 2) in order to reveal the structures of the investigated alloys.

Table 2: Solutions used for sample etching

Tabela 2: Raztopine, uporabljene za jedkanje vzorca

\begin{tabular}{|c|l|}
\hline Sample & Etching solution \\
\hline A1 & $\mathrm{HCl}+\mathrm{H}_{2} \mathrm{O}_{2}+\mathrm{H}_{2} \mathrm{O}$ \\
\hline A2 & $\mathrm{FeCl}_{3}+\mathrm{HCl}+\mathrm{H}_{2} \mathrm{O}$ \\
\hline A3 & $\mathrm{FeCl}_{3}+\mathrm{HCl}+\mathrm{H}_{2} \mathrm{O}$ \\
\hline A4 & $\mathrm{FeCl}_{3}+\mathrm{HCl}+\mathrm{H}_{2} \mathrm{O}$ \\
\hline
\end{tabular}

\section{THEORETICAL FUNDAMENTALS}

Among many available methods for calculating the thermodynamic properties of a ternary system based on the information about the constitutive binary systems, Chou's general solution model (GSM) ${ }^{14,15}$ proved to be the most reasonable in all respects, overcoming the inherent defects of the traditional symmetrical and asymmetrical geometric models. This model breaks down the boundaries between symmetrical and asymmetrical systems and generalizes various situations; the accuracy of the calculation was also proven with practical examples ${ }^{16,17}$.

Recently, a new, improved version of the general solution model based on the Redlich-Kister parameters was presented by Zhang and $\mathrm{Chou}^{18}$. As the older version of GSM required a series of integration processes, which significantly complicated the calculation, and a large number of real systems can be approximately fit using a Redlich-Kister polynomial, a new formalism, based on the binary Redlich-Kister-type parameters, was presented.

Therefore, this new GSM version is utilized for calculating the thermodynamic properties of the $\mathrm{Cu}-\mathrm{Al}-\mathrm{Zn}$ and $\mathrm{Cu}-\mathrm{Mn}-\mathrm{Ni}$ ternary systems.

The basic equation of the general solution model for a ternary system is:

$$
\begin{aligned}
& \Delta G^{\mathrm{E}}=x_{1} x_{2} \sum_{i=0}^{n} L_{12}^{i}\left(x_{1}-x_{2}+\left(2 \xi_{12}-1\right) x_{3}\right)^{i}+ \\
& +x_{2} x_{3} \sum_{i=0}^{n} L_{23}^{1}\left(x_{2}-x_{3}+\left(2 \xi_{23}-1\right) x_{1}\right)^{i}+ \\
& +x_{3} x_{1} \sum_{k=0}^{n} L_{31}^{i k}\left(x_{3}-x_{1}+\left(2 \xi_{31}-1\right) x_{2}\right)^{i}
\end{aligned}
$$

Similarity coefficient $\xi$ is defined as:

$$
\begin{aligned}
& \xi_{12}=\eta_{\mathrm{I}} /\left(\eta_{\mathrm{I}}+\eta_{\mathrm{II}}\right) \\
& \xi_{23}=\eta_{\text {II }} /\left(\eta_{\mathrm{II}}+\eta_{\mathrm{III}}\right) \\
& \xi_{31}=\eta_{\mathrm{III}} /\left(\eta_{\mathrm{III}}+\eta_{\mathrm{I}}\right)
\end{aligned}
$$

and the deviation sum of squares can be calculated using:

$$
\begin{aligned}
& \eta_{\mathrm{I}}=\sum_{l=0}^{n} \frac{1}{2(2 i+1)(2 i+3)(2 i+5)}\left(L_{12}^{i}-L_{13}^{i}\right)^{2}+ \\
& +\sum_{j=0}^{n} \sum_{k>j}^{m} \frac{1}{(j+k+1)(j+k+3)(j+k+5)}\left(L_{12}^{i}-L_{13}^{i}\right)\left(L_{12}^{1}-L_{13}^{1}\right) \\
& \eta_{\mathrm{II}}=\sum_{l=0}^{n} \frac{1}{2(2 i+1)(2 i+3)(2 i+5)}\left(L_{21}^{i}-L_{23}^{i}\right)^{2}+ \\
& +\sum_{j=0}^{n} \sum_{k>j}^{m} \frac{1}{(j+k+1)(j+k+3)(j+k+5)}\left(L_{21}^{i}-L_{23}^{i}\right)\left(L_{21}^{k}-L_{23}^{k}\right) \\
& \eta_{\mathrm{III}}=\sum_{l=0}^{n} \frac{1}{2(2 i+1)(2 i+3)(2 i+5)}\left(L_{31}^{i}-L_{32}^{i}\right)^{2}+ \\
& +\sum_{j=0}^{n} \sum_{k>j}^{m} \frac{1}{(j+k+1)(j+k+3)(j+k+5)}\left(L_{31}^{i}-L_{32}^{i}\right)\left(L_{31}^{k}-L_{32}^{k}\right)
\end{aligned}
$$

The basic equation of the general solution model for a quaternary system ${ }^{19}$ is: 


$$
\begin{aligned}
& \Delta G^{\mathrm{E}}=x_{1} x_{2} \sum_{k=0}^{n} L_{12}^{k}\left(2 X_{1(12)}-1\right)^{k}+x_{1} x_{3} \sum_{k=0}^{n} L_{13}^{k}\left(2 X_{1(13)}-1\right)^{k}+ \\
& +x_{1} x_{4} \sum_{k=0}^{n} L_{14}^{k}\left(2 X_{1(14)}-1\right)^{k}+x_{2} x_{3} \sum_{k=0}^{n} L_{23}^{k}\left(2 X_{2(23)}-1\right)^{k}+ \\
& +x_{2} x_{4} \sum_{k=0}^{n} L_{24}^{k}\left(2 X_{2(24)}-1\right)^{k}+x_{3} x_{4} \sum_{k=0}^{n} L_{34}^{k}\left(2 X_{3(34)}-1\right)^{k}
\end{aligned}
$$

with

$$
\begin{gathered}
X_{i(i j)}=x_{i}+\sum_{\substack{k=1 \\
k \neq i, j}}^{4} \xi_{i(i j)}^{k} x_{k} \\
\xi_{i(i j)}^{k}=\eta_{(i j, i k)} /\left(\eta_{(i j, i k)}+\eta_{(j i, j k)}\right)
\end{gathered}
$$

and

$$
\begin{aligned}
& \eta_{(i j, i k)}=\sum_{l=0}^{n} \frac{1}{2(2 l+1)(2 l+3)(2 l+5)}\left(L_{i j}^{l}-L_{i k}^{l}\right)^{2}+ \\
& +\sum_{l=0}^{n} \sum_{m>l}^{m} \frac{1}{(l+m+1)(l+m+3)(l+m+5)}\left(L_{i j}^{l}-L_{i k}^{l}\right)\left(L_{i j}^{m}-L_{i k}^{m}\right)
\end{aligned}
$$

In Equation (11) the second part is different from zero only if the sum of $m$ and $n$ is an even number, and it applies to all the $L_{i j}$ parameters that $L_{i j}^{k}=(-1)^{k} L^{k} i j$. In all the equations given, $L_{i j}^{v}$ is the Redlich-Kister parameter for the binary system $i j$, independent of the composition and only dependent on the temperature; $\Delta G^{\mathrm{E}}$ is the integral molar excess Gibbs energy for the ternary or quaternary system and $x_{i}$ is the mole fraction of component $i$.

Partial thermodynamic quantities are calculated according to the equations:

$$
G_{i}^{\mathrm{E}}=G^{\mathrm{E}}+\left(1-x_{i}\right)\left(\partial G^{\mathrm{E}} / \partial x_{i}\right)=R T \ln \gamma_{i}
$$

\begin{tabular}{|c|c|c|c|c|}
\hline System $i j$ & $L_{i j}^{o}(T)$ & $L_{i j}^{1}(T)$ & $L_{i j}^{2}(T)$ & $L_{i j}^{3}(T)$ \\
\hline $\mathrm{Al}-\mathrm{Cu}^{20}$ & $-67094+8.555 * T$ & $32148-7.118 * T$ & $5915-5.889 * T$ & $-8175+6.049 * T$ \\
\hline $\mathrm{Cu}-\mathrm{Zn}^{21}$ & $-40695.54+12.65269 * T$ & $4402.72-6.55425^{*} T$ & $7818.1-3.25416 * T$ & 0 \\
\hline $\mathrm{Al}-\mathrm{Zn}^{22}$ & $10465.55-3.39259 T$ & 0 & 0 & 0 \\
\hline $\mathrm{Cu}-\mathrm{Mn}^{23}$ & $1118.55-5.6225 T$ & -10915.375 & 0 & 0 \\
\hline $\mathrm{Cu}-\mathrm{Ni}^{24}$ & $11760+1.084 T$ & -1672 & 0 & 0 \\
\hline $\mathrm{Mn}-\mathrm{Ni}^{25}$ & $-85853+22.715^{*} T$ & $-1620+4.902 * T$ & 0 & 0 \\
\hline $\mathrm{Fe}-\mathrm{Ni}^{26}$ & $-18782+3.7011 * T$ & $12308-2.7599 * T$ & $4457-4.1536 * T$ & 0 \\
\hline $\mathrm{Cu}-\mathrm{Fe}^{27}$ & $+35625.8-2.19045^{*} T$ & $-1529.8+1.15291 * T$ & $+12714.4-5.18624 * T$ & +1177.1 \\
\hline $\mathrm{Fe}-\mathrm{Mn}^{28}$ & $-3950+0.489 * T$ & +1145 & 0 & 0 \\
\hline
\end{tabular}

and:

$$
a_{i}=x_{i} \gamma_{i}
$$

Table 3: Redlich-Kister parameters for constitutive binary systems Tabela 3: Redlich-Kister parametri za konstitutivne binarne sisteme

Table 4: Polynomial form of integral molar excess Gibbs energies calculated using general solution model

Tabela 4: Oblika polinoma integralnih molskih odvečnih Gibbsovih energij, izračunanih z uporabo splošnega modela rešitev

\begin{tabular}{|c|c|c|c|c|}
\hline System & Cross-section & $T / \mathrm{K}$ & $\Delta G^{x s} / \mathrm{J} \mathrm{mol}^{-1}$ & $R^{2}$ \\
\hline $\mathrm{Ni}-\mathrm{Cu}-\mathrm{Fe}-\mathrm{Mn}$ & $\mathrm{Cu}: \mathrm{Fe}: \mathrm{Mn}=20: 1: 1$ & 1873 & $-2180.5 * x_{\mathrm{Ni}}{ }^{3}-622{ }^{*} x_{\mathrm{Ni}}{ }^{2}+7760.2 * x_{\mathrm{Ni}}+643.38$ & 1 \\
\hline $\mathrm{Cu}-\mathrm{Mn}-\mathrm{Ni}$ & $\mathrm{Mn}: \mathrm{Ni}=3: 1$ & 1773 & $13831 * x_{\mathrm{Cu}}{ }^{3}-24352 * x_{\mathrm{Cu}}{ }^{2}+18408 * x_{\mathrm{Cu}}-7883.2$ & 1 \\
\hline $\mathrm{Cu}-\mathrm{Al}-\mathrm{Zn}$ & $\mathrm{Al}: \mathrm{Zn}=1: 2$ & 1373 & $11751 * x_{\mathrm{Cu}}{ }^{2}-7231 * x_{\mathrm{Cu}}-5241.8$ & 0.9895 \\
\hline
\end{tabular}




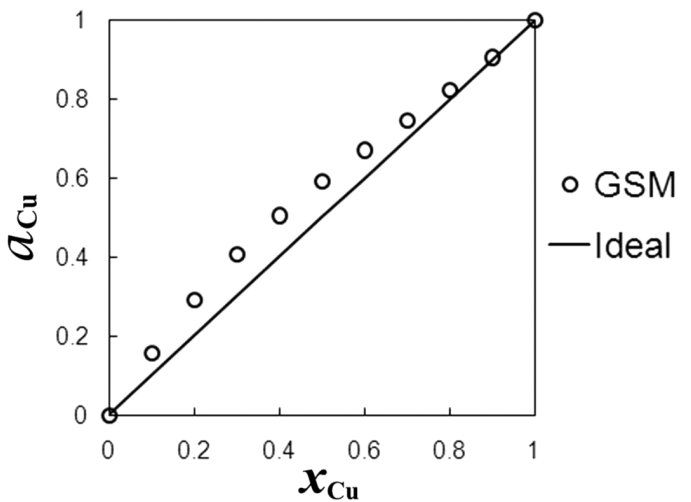

Figure 2: Dependence of copper activity on the composition, for cross-section $\mathrm{Mn}: \mathrm{Ni}=3: 1$ from ternary $\mathrm{Cu}-\mathrm{Mn}-\mathrm{Ni}$ system, calcul ated with GSM, at $1773 \mathrm{~K}$

Slika 2: Odvisnost aktivnosti bakra od sestave, za presek $\mathrm{Mn}: \mathrm{Ni}=3: 1$ $\mathrm{v}$ ternarnem sistemu $\mathrm{Cu}-\mathrm{Mn}-\mathrm{Ni}$, izračunana z uporabo GSM, pri 1773 K

properties calculated with the general solution model are related to the liquid phase of the system, so the temperature, at which the calculation was carried out, was selected according to that rule, taking into account the melting points of all the metals in the investigated system.

From Figure 1, it can be seen that the nickel activity in section $\mathrm{Cu}: \mathrm{Fe}: \mathrm{Mn}=20: 1: 1$ and at $T=1873 \mathrm{~K}$ shows a variable character of the deviation from Raoult's law, where up to $x_{\mathrm{Ni}}=0.4$ the deviation is positive, but with a higher content of nickel in the alloy the deviation becomes negative, indicating that a higher amount of nickel in the alloy leads to a better miscibility of the alloy components.

The copper activity in cross-section $\mathrm{Mn}: \mathrm{Ni}=3: 1$ and at $T=1773 \mathrm{~K}$ (Figure 2) shows a clear positive deviation from Raoult's law, which can even result in an occurrence of layering.

The copper activity in cross-section $\mathrm{Al}: \mathrm{Zn}=1: 2$ and at $T=1373 \mathrm{~K}$ (Figure 3 ) exhibits an apparent negative deviation from Raoult's law, indicating that the

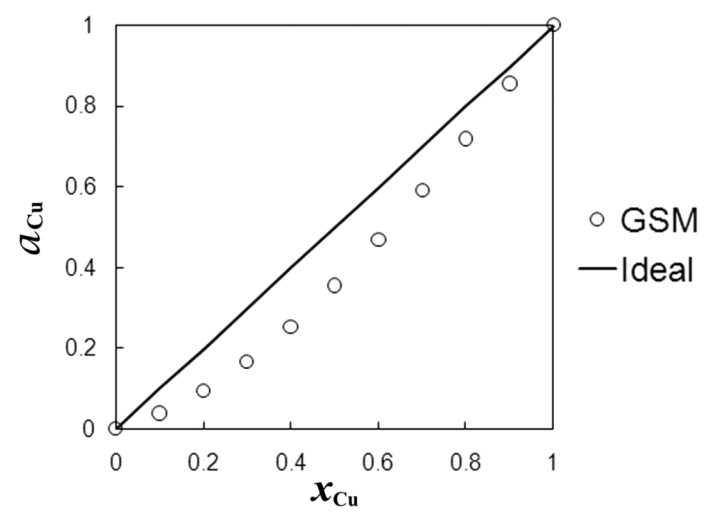

Figure 3: Dependence of copper activity on the composition, for cross-section $\mathrm{Al}: \mathrm{Zn}=1: 2$ from ternary $\mathrm{Cu}-\mathrm{Al}-\mathrm{Zn}$ system, calculated with GSM, at $1373 \mathrm{~K}$

Slika 3: Odvisnost aktivnosti bakra od sestave, za presek $\mathrm{Al}: \mathrm{Zn}=1: 2$ v ternarnem sistemu $\mathrm{Cu}-\mathrm{Al}-\mathrm{Zn}$, izračunana z uporabo GSM, pri $1373 \mathrm{~K}$
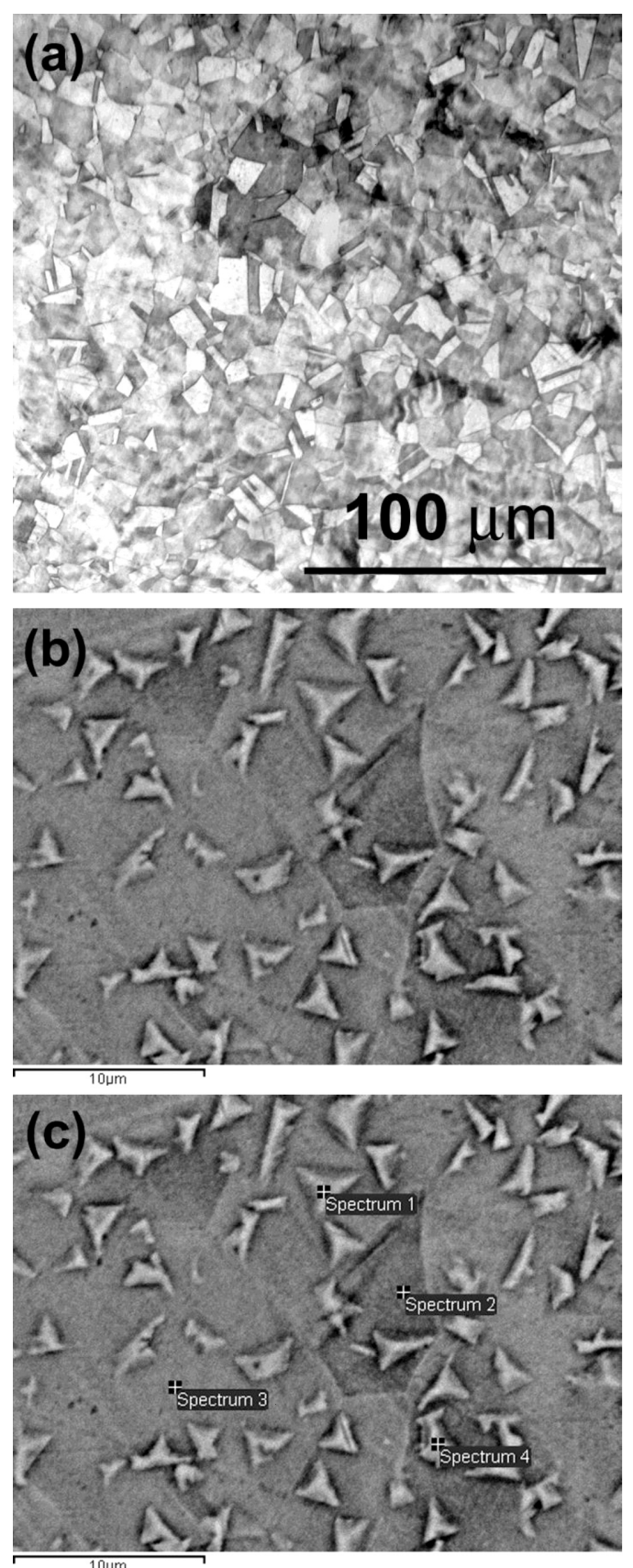

Figure 4: Microstructure of sample A1: a) LM (magnification of $500 \times$ ), b) SEM (magnification of $4000 \times$ ) and c) positions of EDX analysis

Slika 4: Mikrostruktura vzorca A1: a) LM (povečava 500×), b) SEM (povečava $4000 \times$ ) in c) položaj EDX-analiz

Table 5: Results of EDX analysis of sample A1 in amount fractions, $(x / \%)$

Tabela 5: Rezultati EDX-analiz vzorca A1 v množinskih deležih, $(x / \%)$

\begin{tabular}{|c|c|c|c|c|}
\hline \multirow{2}{*}{ Position } & \multicolumn{4}{|c|}{$\mathrm{A} 1$} \\
\cline { 2 - 5 } & $\mathrm{Mn}$ & $\mathrm{Fe}$ & $\mathrm{Ni}$ & $\mathrm{Cu}$ \\
\hline Spectrum 1 & 1.23 & 1.52 & 65.49 & 31.75 \\
\hline Spectrum 2 & 1.20 & 1.69 & 66.63 & 30.48 \\
\hline Spectrum 3 & 1.26 & 1.67 & 67.95 & 29.12 \\
\hline Spectrum 4 & 1.31 & 1.27 & 64.97 & 32.46 \\
\hline
\end{tabular}


miscibility of the metals in the ternary $\mathrm{Cu}-\mathrm{Al}-\mathrm{Zn}$ system is quite good.

The results of the microstructural analysis with light optical microscopy and SEM-EDX for sample A1 are given in Figure 4, with the chemical composition determined with EDX presented in Table 5.

The microphotograph obtained with LM (Figure 4a) shows that the alloy structure consists of sharp-edged polygonal grains.

The SEM image on Figure $\mathbf{4 b}$ reveals the structure of sample A1 as a gray matrix with imbedded triangular grains, but the EDX analysis shows that the grains and the matrix have almost identical chemical compositions. These findings are in agreement with the fact that copper and nickel, two components that together account for
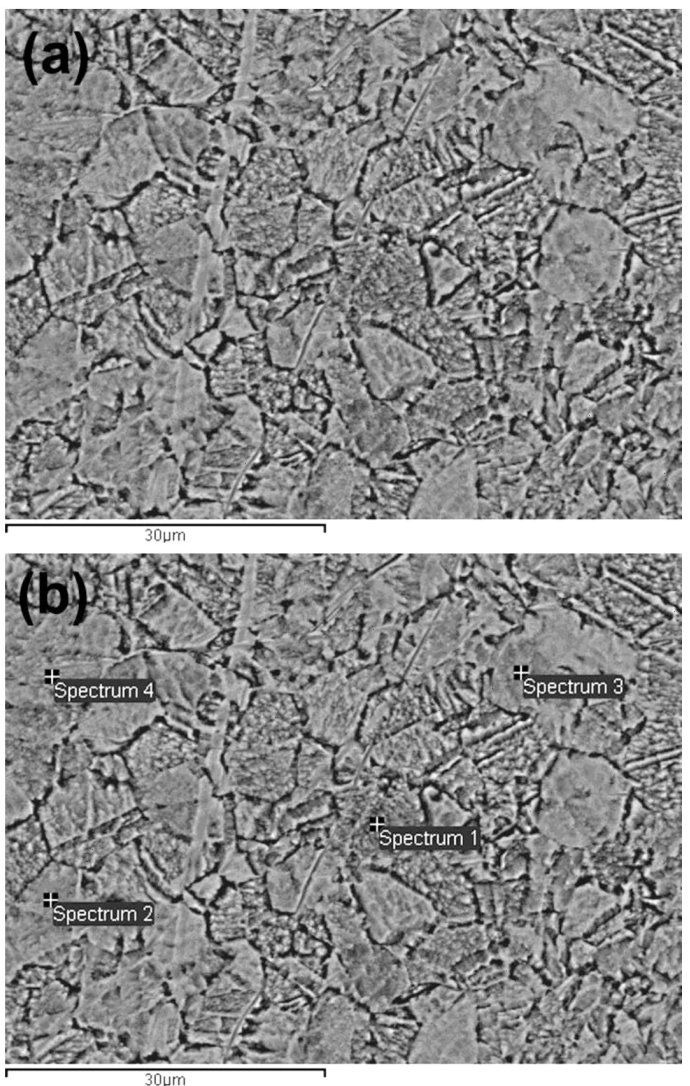

Figure 5: Microstructure of sample A2: a) SEM (magnification of $2000 \times$ ) and b) positions of EDX analysis

Slika 5: Mikrostruktura vzorca A2: a) SEM (povečava 2000×) in b) položaj EDX-analiz

Table 6: Results of EDX analysis of sample A2 in amount fractions, $(x / \%)$

Tabela 6: Rezultati EDX-analiz vzorca A2 v množinskih deležih, $(x / \%)$

\begin{tabular}{|c|c|c|c|}
\hline \multirow{2}{*}{ Position } & \multicolumn{3}{|c|}{$\mathrm{A} 2$} \\
\cline { 2 - 4 } & $\mathrm{Mn}$ & $\mathrm{Ni}$ & $\mathrm{Cu}$ \\
\hline Spectrum 1 & 15.04 & 4.70 & 80.25 \\
\hline Spectrum 2 & 14.92 & 4.50 & 80.58 \\
\hline Spectrum 3 & 15.11 & 4.48 & 80.41 \\
\hline Spectrum 4 & 15.35 & 4.41 & 80.24 \\
\hline
\end{tabular}

over $90 \%$ of the alloy's mass, form a continuous series of solid solutions ${ }^{29}$.
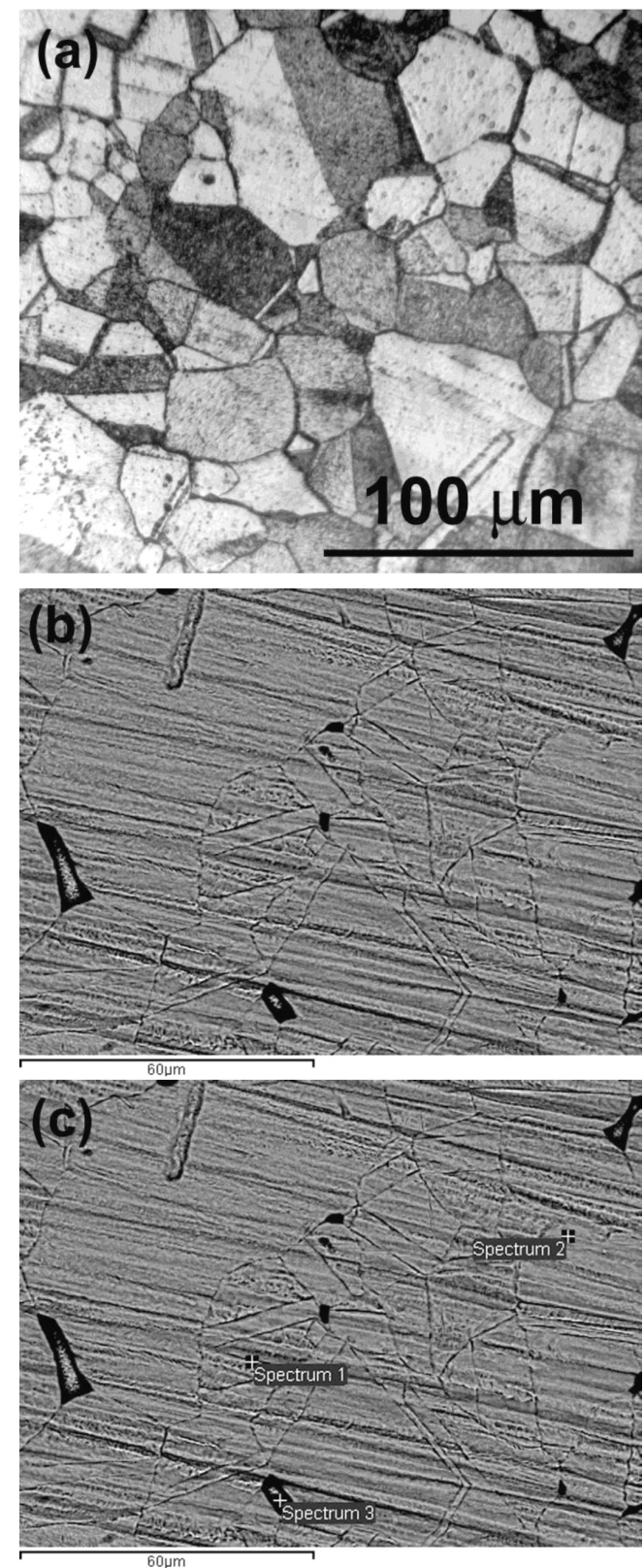

Figure 6: Microstructure of sample A3: a) LM (magnification of $500 \times$ ), b) SEM-EDX (magnification of $1000 \times$ ) and $c$ ) positions of EDX analysis

Slika 6: Mikrostruktura vzorca A3: a) LM (povečava 500×), b) SEM-EDX (povečava 1000×) in c) položaj EDX-analiz

Table 7: Results of EDX analysis of sample A3 in amount fractions, $(x / \%)$

Tabela 7: Rezultati EDX-analiz vzorca A3 v množinskih deležih, $(x / \%)$

\begin{tabular}{|c|c|c|c|}
\hline \multirow{2}{*}{ Position } & \multicolumn{3}{|c|}{$\mathrm{A} 3$} \\
\cline { 2 - 4 } & $\mathrm{Al}$ & $\mathrm{Cu}$ & $\mathrm{Zn}$ \\
\hline Spectrum 1 & 8.83 & 69.75 & 21.42 \\
\hline Spectrum 2 & 7.93 & 71.11 & 20.96 \\
\hline Spectrum 3 & 1.11 & 78.03 & 20.87 \\
\hline
\end{tabular}


The results of the microstructural analysis with light microscopy and SEM for sample A2 are given in Figure
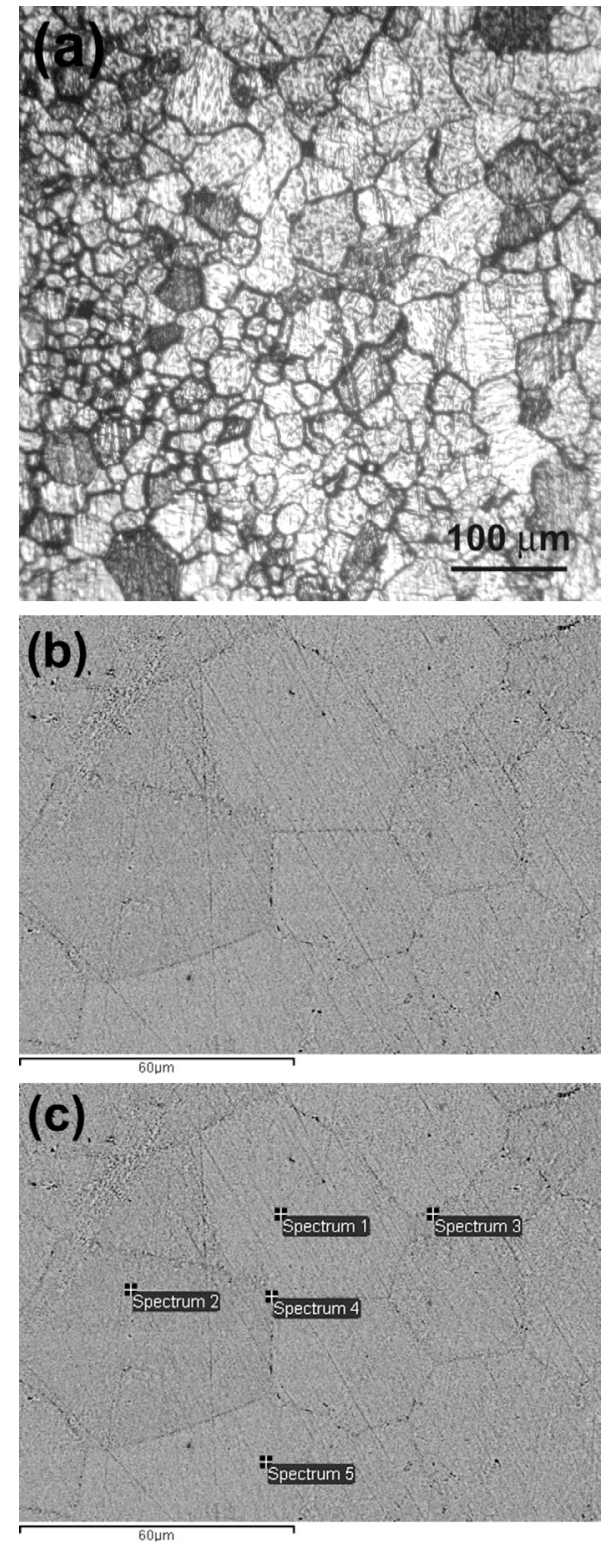

Figure 7: Microstructure of sample A4: a) LM (magnification of $80 \times$ ), b) SEM-EDX (magnification of $1000 \times$ ) and c) positions of EDX analysis

Slika 7: Mikrostruktura vzorca A4: a) LM (povečava $80 \times$ ), b) SEM-EDX (povečava 1000x) in c) položaj EDX-analiz

Table 8: Results of EDX analysis of sample A4 in amount fractions, $(x / \%)$

Tabela 8: Rezultati EDX-analiz vzorca A4 v množinskih deležih, $(x / \%)$

\begin{tabular}{|c|c|c|c|}
\hline \multirow{2}{*}{ Position } & \multicolumn{3}{|c|}{$\mathrm{A} 4$} \\
\cline { 2 - 4 } & $\mathrm{Al}$ & $\mathrm{Cu}$ & $\mathrm{Zn}$ \\
\hline Spectrum 1 & 12.14 & 63.45 & 24.41 \\
\hline Spectrum 2 & 11.95 & 64.22 & 23.83 \\
\hline Spectrum 3 & 12.03 & 63.60 & 24.37 \\
\hline Spectrum 4 & 12.09 & 63.66 & 24.25 \\
\hline Spectrum 5 & 12.10 & 63.15 & 24.76 \\
\hline
\end{tabular}

5 and the chemical compositions determined with the EDX analysis are presented in Table 6.

Technical difficulties like the fact that the maximal magnification of the LM apparatus is just 500x and a very small diameter $(1 \mathrm{~mm})$ of sample A2 prevented us from getting a LM photograph.

The microstructure of sample A2 (Figure 5b) is characterized by the grains irregular in the shape and size, and the results of the EDX analysis presented in Table 6 are consistent with the fact that copper forms solid solutions with nickel and manganese ${ }^{29}$.

The results of the microstructural analysis with light optical microscopy and SEM for sample A3 are given in Figure 6, with the chemical compositions determined with the EDX analysis presented in Table 7.

The microstructure of alloy A3, obtained with a LM microphotograph (Figure 6a), consists of polygonal grains with a significant variation in size.

The results of the microstructural analysis with light optical microscopy and SEM-EDX for sample A4 are given in Figure 7 and the chemical compositions determined with the EDX analysis are presented in Table 8. The microstructure of sample A4 consists of polygonal grains, which vary in size.

According to the phase diagram of the binary $\mathrm{Cu}-\mathrm{Zn}$ and $\mathrm{Cu}-\mathrm{Al}$ systems ${ }^{29}$, the solid solubility of aluminum in copper is approximately $18 \%$ of amount fractions, and for zinc it goes up to $30 \%$ of amount fractions. Considering that the base material for samples A3 and A4 is copper $(\approx w(\mathrm{Cu})=68 \%)$, it is reasonable to expect that aluminum and zinc will dissolve in copper, creating solid solutions. This was confirmed with the results of the EDX analysis presented in Tables 7 and 8. In addition, the EDX results indicate that the homogeneity of sample A4 is quite good because there is no significant difference in the chemical composition analyzed at various measuring points.

\section{CONCLUSION}

Different shape-memory alloys belonging to ternary systems $\mathrm{Cu}-\mathrm{Al}-\mathrm{Zn}$ and $\mathrm{Cu}-\mathrm{Mn}-\mathrm{Ni}$ and to quaternary system $\mathrm{Ni}-\mathrm{Cu}-\mathrm{Fe}-\mathrm{Mn}$ were investigated. The termodynamic properties of these alloys were investigated analytically, using the general solution model (GSM) and the known Redlich-Kister parameters for the constitutive binary systems. The thermodynamic analysis showed that the alloys with high copper amounts from systems $\mathrm{Cu}-\mathrm{Al}-\mathrm{Zn}$ and $\mathrm{Ni}-\mathrm{Cu}-\mathrm{Fe}-\mathrm{Mn}$ display a good miscibility, while the alloys from the $\mathrm{Cu}-\mathrm{Mn}-\mathrm{Ni}$ system tend to display positive deviations from Raoult's law, which can even lead to layering.

The microstructures of the selected alloys were investigated experimentally by means of light optic microscopy (LM) and scanning electron microscopy with energy-dispersive X-ray spectrometry (SEM-EDX). The microstructure analysis of the investigated alloy samples 
revealed that the microstructure is built of polygonal grains that can significantly vary in size. The EDX analysis results provided the information about the alloy chemical compositions and were, overall, in agreement with the known facts about the investigated systems. The results presented in this paper contribute to a better understanding of the thermodynamic properties and microstructures of the investigated shape-memory alloys.

\section{Acknowledgement}

The authors are grateful to the Ministry of Education, Science and Technological Development of the Republic of Serbia for the financial support provided through Projects 34005 "Development of ecological knowledge-based advanced materials and technologies for multifunctional application" and 172037 "Modern multi-component metal systems and nanostructured materials with different functional properties".

\section{REFERENCES}

${ }^{1}$ W. M. Huang, Z. Ding, C. C. Wang, J. Wei, Y. Zhao, H. Purnawali, Shape memory materials, Materials Today, 13 (2010) 7-8, 54-61, doi:10.1016/S1369-7021(10)70128-0

${ }^{2}$ D. Achitei, P. Vizureanu, N. Cimpoesu, D. Dana, Thermo-mechanical fatigue of $\mathrm{Cu}-\mathrm{Al}-\mathrm{Zn}$ shape memory alloys, Proc. of $44^{\text {th }}$ International October Conference on Mining and Metallurgy, Bor, 2012, 401-404

${ }^{3}$ L. Janke, C. Czaderski, M. Motavalli, J. Ruth, Applications of shape memory alloys in civil engineering structures - Overview, limits and new ideas, Materials and Structures, 38 (2005), 578-592, doi:10.1007/BF02479550

${ }^{4}$ K. K. Jee, J. H. Han, W. Y. Jang, A method of pipe joining using shape memory alloys, Materials Science and Engineering A, 438-440 (2006), 1110-1112, doi:10.1016/j.msea.2006.02.094

${ }^{5}$ Y. Bellouard, Shape memory alloys for microsystems: A review from a material research perspective, Materials Science and Engineering A, 481-482 (2008), 582-589, doi:10.1016/j.msea.2007.02.166

${ }^{6}$ D. Mantovani, Shape Memory Alloys: Properties and Biomedical Applications, Journal of the Minerals Metals and Materials Society, 10 (2000), 36-44, doi:10.1007/s11837-000-0082-4

${ }^{7}$ A. Melzer, D. Stöckel, Using shape-memory alloys, Medical Device Technology, 6 (1995) 4, 16-23

${ }^{8}$ Y. Luo, M. Higa, S. Amae, T. Yambe, T. Okuyama, T. Takagi, H. Matsuki, The possibility of muscle tissue reconstruction using shape memory alloys, Organogenesis, 2 (2005) 1, 2-5, doi:10.4161/org. 2.1.1757

${ }^{9}$ M. Dolce, D. Cardone, R. Marnetto, Implementation and testing of passive control devices based on shape memory alloys, Earthquake Engineering and Structural Dynamics, 29 (2000), 945-968, doi:10.1002/1096-9845(200007)29:7<945::AID-EQE958>3.0.CO;2\#

${ }^{10}$ S. Saadat, J. Salichs, M. Noori, Z. Hou, H. Davoodi, I. Bar-On, Y Suzuki, A. Masuda, An overview of vibration and seismic applications of NiTi shape memory alloy, Smart Materials and Structures, 11 (2002), 218-229, doi:10.1088/0964-1726/11/2/305

${ }^{11}$ R. DesRoches, B. Smith, Shape memory alloys in seismic resistant design and retrofit: a critical review of their potential and limitations, Journal of Earthquake Engineering, 8 (2004) 3, 415-429, doi:10.1080/13632460409350495
${ }^{12}$ B. Kim, M. G. Lee, Y. P. Lee, Y. I. Kim, G. H. Lee, An earthworm-like micro robot using shape memory alloy actuator, Sensors and Actuators A: Physical, 125 (2006), 429-437, doi:10.1016/ j.sna.2005.05.004

${ }^{13}$ R. B. Gorbet, R. A. Russell, A novel differential shape memory alloy actuator for position control, Robotica, 13 (1995), 423-430, doi:10.1017/S0263574700018853

${ }^{14}$ K. C. Chou, A general solution model for predicting ternary thermodynamic properties, Calphad, 19 (1995), 315-325, doi:10.1016/ 0364-5916(95)00029-E

${ }^{15}$ K. C. Chou, S. K. Wei, A new generation solution model for predicting thermodynamic properties of a multicomponent system from binaries, Metallurgical and Materials Transactions B, 28 (1997), 439-445, doi:10.1007/s11663-997-0110-7

${ }^{16}$ Lj. Balanović, D. Živković, A. Mitovski, D. Manasijević, Ž. Živković, Calorimetric investigations and thermodynamic calculation of Zn-Al-Ga system, Journal of Thermal Analysis and Calorimetry, 103 (2011) 3, 1055-1061, doi:10.1007/s10973-010-1070-8

${ }^{17}$ L. Gomidželović, I. Mihajlović, A. Kostov, D. Živković, Cu-Al-Zn System: Calculation of thermodynamic properties in liquid phase, Hemijska Industrija, 67 (2013) 1, 157-164, doi:10.2298/HEMIND $120306041 \mathrm{G}$

${ }^{18}$ G. H. Zhang, K. C. Chou, General formalism for new generation geometrical model: application to the thermodynamics of liquid mixtures, Journal of Solution Chemistry, 39 (2010), 1200-1212, doi:10.1007/s10953-010-9570-5

${ }^{19}$ G. H. Zhang, L. J. Wang, K. C. Chou, A comparison of different geometrical models in calculating physicochemical properties of quaternary systems, Calphad, 34 (2010) 4, 504-509, doi:10.1016/ j.calphad.2010.10.004

${ }^{20}$ V. T. Witusiewicz, U. Hecht, S. G. Fries, S. Rex, The Ag-Al-Cu system: Part I: Reassessment of the constituent binaries on the basis of new experimental data, Journal of Alloys and Compounds, 385 (2004), 133-143, doi:10.1016/j.jallcom.2004.04.126

${ }^{21}$ A. T. Dinsdale, A. Kroupa, J. Vizdal, J. Vrestal, A. Watson, A. Zemanova, COST Action MP0602, Version 1.0, Thermodynamic Database, Brno, Czech Republic, 2009 (http://www.cost.eu/COST_ Actions/mpns/Actions/MP0602)

${ }^{22} \mathrm{~S}$. Mey, Re-evaluation of the Al-Zn system, International Journal of Materials Research, 84 (1993) 7, 451-455

${ }^{23}$ C. He, Y. Du, H. L. Chen, S. Liu, H. Xu, Y. Ouyang, Z. K. Liu, Thermodynamic modeling of the $\mathrm{Cu}-\mathrm{Mn}$ system supported by key experiments, Journal of Alloys and Compounds, 457 (2008), 233-238, doi:10.1016/j.jallcom.2007.03.041

${ }^{24} \mathrm{~J}$. Miettinen, Thermodynamic description of the $\mathrm{Cu}-\mathrm{Mn}-\mathrm{Ni}$ system at the $\mathrm{Cu}-\mathrm{Ni}$ side, Calphad, 27 (2003) 2, 147-152, doi:10.1016/ j.calphad.2003.08.003

${ }^{25} \mathrm{~J}$. Miettinen, Thermodynamic solution phase data for binary Mnbased systems, Calphad, 25 (2001) 1, 43-58, doi:10.1016/S03645916(01)00029-3

${ }^{26}$ G. Cacciamani, A. Dinsdale, M. Palumbo, A. Pasturel, The Fe-Ni system: Thermodynamic modelling assisted by atomistic calculations, Intermetallics, 18 (2010), 1148-1162, doi:10.1016/j.intermet. 2010.02.026

${ }^{27}$ Q. Chen, Z. P. Jin, The Fe-Cu system: A thermodynamic evaluation, Metallurgical and Materials Transactions A, 26 (1995) 2, 417-426, doi:10.1007/BF02664678

${ }^{28}$ W. Huang, An Assessment of the Fe-Mn system, Calphad, 13 (1989) 3, 243-252, doi:10.1016/0364-5916(89)90004-7

${ }^{29} \mathrm{http} / / / \mathrm{www} . \mathrm{crct}$. polymtl.ca/fact/documentation/sgte/sgte_figs.htm 